Article

\title{
Knowledge Management in Households about Energy Saving as Part of the Awareness of Sustainable Development
}

\author{
Justyna Żywiołek $^{1, *(\mathbb{D} \text {, Joanna Rosak-Szyrocka }}{ }^{1}$ and Maciej Mrowiec ${ }^{2}$ \\ 1 Faculty of Management, Czestochowa University of Technology, 42-200 Czestochowa, Poland; \\ joanna.rosak-szyrocka@wz.pcz.pl \\ 2 Faculty of Infrastructure and Environment, Czestochowa University of Technology, \\ 42-200 Czestochowa, Poland; maciej.mrowiec@pcz.pl \\ * Correspondence: justyna.zywiolek@wz.pcz.pl; Tel.: +48-343-250-399
}

Citation: Żywiołek, J.;

Rosak-Szyrocka, J.; Mrowiec, M.

Knowledge Management in

Households about Energy Saving as

Part of the Awareness of Sustainable

Development. Energies 2021, 14, 8207.

https://doi.org/10.3390/en14248207

Academic Editor: Nuno Carlos Leitão

Received: 6 November 2021

Accepted: 1 December 2021

Published: 7 December 2021

Publisher's Note: MDPI stays neutral with regard to jurisdictional claims in published maps and institutional affiliations.

Copyright: (C) 2021 by the authors. Licensee MDPI, Basel, Switzerland. This article is an open access article distributed under the terms and conditions of the Creative Commons Attribution (CC BY) license (https:/ / creativecommons.org/licenses/by/ $4.0 /)$.

\begin{abstract}
Energy conservation is a popular topic in scientific research today, despite the specific effects of energy conservation awareness still being investigated. Significant research about this topic has been performed in different countries. However, the research conducted so far concerns methods of energy saving, a building's energy efficiency and new technologies; however, a significant part of society will live in technologically old buildings for a long time, which requires the involvement of consumers to save energy. To explain how energy-saving awareness plays a role in energy-saving behavior, this study will take city dwellers as a research facility and integrate relevant literature and disciplines, such as information and knowledge management, with the mechanistic study of how energy-saving awareness influences behavior that conserves energy and establishes a sensible behavior model. The survey was conducted in Poland, Portugal and Italy with over 18,000 people who declared that they are responsible for managing the household. In addition to the quantitative and qualitative research defining the percentage of behavior, the research group gave answers to the assessment of energy management, both assessing itself and the activities carried out in its own households on the Likert scale. The SERVPERF method was used for this. The results of the study clearly show that not only do economic factors affect energy saving, but also an informed society that cares about resource management. The research carried out presents the measures undertaken to save energy, and also identifies the level of knowledge and behavior that reflect pro-ecological trends and care for the sustainable development of the city, country and one's own household.
\end{abstract}

Keywords: energy management; energy saving; household energy

\section{Introduction}

The growing economic, social and environmental problems in the modern world determine the processes of purchasing and consuming goods [1]. It becomes necessary to replace traditional consumption in terms of assortment, space and time with sustainable consumption [2], which is understood as the conscious and responsible use of natural resources, goods and services, in accordance with the principles of sustainable development [3]. It is primarily about energy resources being used conciously. Transformation in the area of consumption takes place at the level of individuals, households, local communities, business environments, local governments, national governments and international structures [4-6]. Progress in the field of sustainable development, based mainly on waste reduction, the production of waste and pollution and the selection of goods and services that meet certain ethical and environmental criteria, is possible only when making changes at all levels, including households [7-10]. The demand felt by the consumer for products, services or solutions, reflected in his/her purchasing decisions and subsequent consumption, initiate these processes [11,12]. The degree of sustainable use of resources for their consumption depends on many factors, such as the environmental and social attitudes of producers and financial possibilities $[13,14]$. Sustainable consumption patterns are mainly 
adapted in households, where decisions are made regarding the choice of needs and ways of satisfying them [15-17]. The realization of ideas about the best ways to meet common and individual needs results in the purchase of specific goods and services or the limitation of use, as a result of individual needs or to reduce costs [18].

As part of the economic functioning of the household, decisions are made regarding their distribution. Assuming that sustainable consumption is based, inter alia, on making decisions about the purchase of goods (and limiting their consumption [19]), verifying their actual necessity and the impact on the household, in terms of awareness, finances and the environment, the article presents an analysis of household expenditure in Poland, Italy and Portugal.

The empirical study of energy expenditure was conducted on the basis of individual data from a study conducted in 2019-2020. The household budget survey is representative. The results of the observations made in the studied sample can therefore be used, with high probability, to describe and analyze the entire surveyed community. The research goal was to verify to what extent the changes in people's awareness and management of their knowledge affect energy saving and correspond to the sphere of behavior supporting environmental protection. Determining the research goal of the paper requires asking research questions: what factors determine the behavior of energy management skills in households and how the level of knowledge influences on energy saving behavior.

\section{Review of Literature}

The energy issue has now become a national policy issue, and energy scarcity is also a global challenge [20]. Since the 1990s, continuous economic development has led to a rapid increase in energy consumption [21-23]. As a result, energy consumption in residential buildings has become an important growth factor. Therefore, it is especially important to manage energy-saving behavior $[23,24]$.

In studying individual behavior, scientists have advanced many theories to explain personal behavior. The theory of planned behavior provides a valuable theoretical perspective for understanding individual energy-saving behavior and is one of the more relatively well-developed and effective research theories in the field of behavior [25,26]. Ajzen has added the Perceived Behavior Control variable based on rational behavior theory, while Justin Paul et al. have added environmental variables to the study of predicting the consumption of organic products to predict consumer behavior [27-29]. Chen and Tung have constructed a theoretical model of expanded plan behavior that includes environmental awareness and perceptual moral obligation [30-32]. Klöckner has proposed a comprehensive model using a meta-analytical approach to structural equation modeling, based on a pool of 56 different data sets with different target behaviors [33].

The research on energy-saving awareness and behavior to date is mainly related to the designed scale and to research that analyzes the relationship between these two factors. Based on the theory of planned behavior, this article explores the relationship between energy-saving awareness and energy-saving behavior in residential life [34].

The definition of energy-saving awareness is a fundamental question, but also a controversial one in the field of management and the technology itself, and has not reached a consensus [35]. Some researchers have suggested that the concepts of behavior cannot be defined because behavioral research is still incomplete, just as the meanings and functions of behavior are still unknown. Others realize that an exact definition is not necessary and may only offer research aspects and boundaries for such an issue [18,36,37].

So far, the understanding of human brain function is still very limited, as cognition and consciousness cannot be directly explained from a knowledge management perspective. This article suggests that giving a comprehensive definition of consciousness is a difficult task [38]. Therefore, it is permissible for now to study and analyze behavior in a specific environment and provide a definition in that specific state. Such research uses understanding in consciousness from the point of view of managing the consumer's knowledge, and analyzing economic factors to investigate the influence of consciousness 
on behavior at the level of energy-saving awareness as an individual's understanding of energy issues, energy-saving emotional judgments, intention to choose to save energy, individual behavior, and generating, sustaining and terminating others forms of psychological activity [34,39]. It follows from the above definition that the awareness of energy efficiency is not only a few factors of awareness or the sum of ideological forms. Rather, it is a kind of continuous state by monitoring each process and the result of the consumer's activities $[35,40]$.

Stern believes that we can define environmental behavior based on the two dimensions of "impact" and "intention" [24,41,42]. The impact-oriented definition deals with the environmental impact on a behavior. An intention-oriented definition emphasizes the purpose of individual behavior. It also points out that an impact-oriented definition can better analyze the target behavior and understand the real environmental impact of the target behavior. If a researcher wants to understand and change some of the environmental behaviors that people regularly perform, do, or want to do, they should.

A balanced consumer is a consumer whose purchasing decisions are in line with the implementation of the idea of sustainable development, and thus taking sustainable consumption $[43,44]$. In terms of sustainable consumption, we can distinguish weak and strong sustainable consumption. Poor sustainable consumption is rooted in the market approach and is based on technological optimism [23,45]. In contrast, strong sustainable consumption highlights the key role of social innovation as a starting point for its implementation [34,46]. The weak approach is such that sustainable consumption can be achieved by improving product performance (e.g., energy efficiency) that results from technological solutions that will spread through the markets due to consumer demand [47]. Strong sustainable consumption, on the other hand, is based on the assumption that changes in consumption and its patterns are necessary [36]. Poor sustainable consumption is necessary for the implementation of the sustainable development strategy, but is clearly not sufficient. Strong sustainable consumption is essential, with an emphasis on lowering consumption levels and simplifying lifestyles [1,48,49].

An expression of strong sustainable consumption is the increasingly frequent attitudes and behaviors of consumers, manifested in the pursuit of moderation in purchasing new goods and searching for and consuming products that do not destroy the natural environment. This tendency is characterized by aiming rational choices to achieve consumer equilibrium, and also to achieve the goals of sustainable development.

The discussed research problems are not reflected in reports or previously published scientific research. Assuming that there are no previous analyzes for granted, the following is a literature review on this subject, exploring the problem of a research nature $[45,50]$. Energy sector companies make a significant contribution to solving environmental and social problems related to sustainable consumption. Scientific research is often focused on ecological and social threats. The impact of these threats on the Earth's condition is also not without significance. S. Jeanrenaud and J.-P. Jeanrenaud have referred not only to the ecological and social threats themselves, but they implicate them by linking them with the challenges of sustainable development and directing the attention of researchers to the problem of key environmental challenges, for example, the problem of depletion of natural resources. M. Lenox and A. Chatterji have emphasized that the planet is in deepening trouble due to ecological and social threats. These threats of change, neglect and the pursuit of "unsustainable development" of the environment have led to disastrous predictions for the inhabitants of land and sea and their future. For example, J. A. Carbo expresses equally less optimistic opinions when he states that, from an ecological point of view, modern business methods of marketing, mining, production and utilization inhibit a sustainable planet that is at a catastrophic level of destruction [11]. The number of ecological and social threats and the rate of their increase has led to the conceptualization of sustainable development and attempts to implement it. The concept of "sustainable development" is understood as the ability of all or part of an environmental biome to expand its form in the future [19]. The term sustainable development is used without any consequences and 
often has different meanings for different people and organizations, which is a result from its wide application.

Multiple definitions of the concept of sustainable development are presented in the literature. Sustainable development is the involvement of forces and resources primarily in the process of change. A light and gentle approach to the interpretation of the concept means that we have to allow that some resources are to be replaced by others. The epotechnical, resource-based approach assumes socio-economic modernization and progress thanks to the maximum use of resources with the smallest and minimum share of natural resources. Sustainable development has become a key business task: to create developments that cause minimal negative effects on the environment. To be aware of the need for a future for people and the planet is a testament to a company's long-term success.

The research described by scientists takes into account the various problems relating to the energy industry and the aspect of sustainable development. In the literature, T. E. Thorhallsdottir has described the problem of energy assessment and the ranking of projects that could have an impact on Iceland's environment. In turn, Pang et al. has tried to create a way to comprehensively assess sustainability among energy models that have been previously developed.

The multiplicity of approaches, studies, reports and even local or social activity does not solve this problem. It shows that there are still no solutions, and that their number is insufficient for the needs. Community involvement is still insufficient; the awareness of the large concerns and their involvement in such activities on a global scale is essential. The involvement of companies is often symbolic. Moreover, sustainable management is a relatively modern concept that can also accelerate these actions towards sustainable development in the energy sector. The process of sustainable management is primarily about achieving goals with the principles of sustainable development.

Organizational processes also require changes in favor of sustainable development. Social, environmental and economic issues should be integrated into all areas of human activity at work or at home [51-55]. In enterprises, such processes are somehow forced on departments or individual employees. However, households have limited knowledge, cognitive abilities and goal financing. Organizing and performing duties and activities necessary for the functioning of the household should be pro-ecological and pro-social for the purposes and goals of society. In this case, it is about the use of an economical and safe device, the use of ecological materials, compliance with health and safety rules and compliance with labor law. In addition, it is recommended that in order to achieve a social effect, city authorities and social groups should create special pro-social programs that are not imposed by applicable law, such as waste segregation or a work-life balance. Motivation is an important function of sustainable management, and thus understanding your motivation is key to managing people effectively. A high motivation allows you to use $80-90 \%$ of people's potential [56-59].

The analysis of the literature shows that sustainable development and energy saving subject is very popular [55]. However, none of these analyzes concerns pro-social and pro-ecological behaviors $[2,60]$, saving methods and activities and principles evaluation aimed at saving energy, thanks to the SERVPERF method on its specific scale. The study fills the gap in consumer awareness, as the methods themselves are already known. However, there is no research on their conscious use with an indication of the activities' quality. The methodology allows for the adopted study of a large group in different countries during the prevailing pandemic. Previous studies were concerned of only part of the necessary behaviors and knowledge of consumers. The lack of a two-stage study resulted in the limit of a study to the ways of saving but did not give an image of knowledge and awareness. Previous research often did not concern households themselves, as most of them concern industry where energy itself is not treated separately [61-63]. Most research is concerned of renewable energy sources or the consumption of water and energy [47]. 


\section{Materials and Methods}

The aim of the research is to determine to what level household managers are proecological and pro-social, and how quickly they learn or know how to manage energy in households. The interest in this problem results from the view that the future of sustainable development for activities in the energy sector depends on the attitudes of generations and the preferences of the generations. The adoption of such a research goal is justified by a review and analysis of the literature. The research shows that the structure of the analyzed attitudes, views and behaviors are derived from knowledge about energy management. A research tool in the form of a questionnaire was developed to conduct the study. In order to achieve the aim of the study, the sample size and the method of communication with the respondents were determined. It was decided to opt for an online questionnaire available in three native languages. The questionnaire contained 15 questions on energy and resource saving behavior in households, which was the first part of the study. This part of the results was also statistically analyzed. The $X^{2}$ test (chi-squared) was performed, and the qualitative indicators were calculated to determine the relationships as well as their strengths. The second part of the study consisted of 11 targeted questions for the SERVPERF method. Behavior and the way of transferring knowledge have been tested on a seven-point scale.

The choice of such a scale was related to the possibility of classifying respondents with low, medium or high pro-ecological and pro-social orientation, and allows for the formulation of conclusions about their future behavior and the way of transferring knowledge. The study was conducted in Poland, Italy and Portugal at the same time in January and February 2020. The research questionnaire contained 11 directed questions to solve a research problem. Each question had a point scale on which to answer. The research group consisted of 18,421 people: the number of full questionnaires that were completed in all countries. The study also included a certificate describing age, gender, salary, profession and the level of knowledge about energy management in the household.

The research was focused on the preferences and behaviors of household managers, and was carried out using a representative method. The course of the study included 18,421 people, aged $19-55$ years. In determining the necessary sample size, the following steps were taken:

- the accuracy of the estimation was established assuming a certain error of the maximum estimate,

- assumed a high level of confidence

- assumptions were made regarding the proportions of the studied population.

The number of respondents met the minimum sample size assumptions. The research was conducted in Poland, Italy and Portugal. These countries strive for adequate energy management, cooperate with each other in energy management and the sustainable use of resources. They have similar goals, plans and assumptions in this respect. The promotion of appropriate behavior in their societies and the education of citizens evoke positive public responses. European citizens have a similar level of economic development and cultural profile, and the possibility of free movement between the countries belonging to the European Union provides an opportunity [51] to exchange knowledge, views and observe solutions $[29,64]$. To show the similarities between countries, it should be noted how many households are in the surveyed countries (Table 1).

Despite differences in the size of the country, there is a noticeable common feature of the average household size. Table 2 shows the percentage of energy consumption by household equipment.

The adoption of the principles of sustainable consumption in household expenditures is manifested in the consumption of so-called ecological goods and the economical and rational use of consumer goods. An important symptom of sustainable consumption is the quantitative reduction in the consumption of goods with a high absorption of nonrenewable resources. These behaviors are known as environmental deconsumption. A reflection of the quantitative consumption of electricity in households is the expenditure 
on energy carriers. In the study of household budgets under the analyzed expenditure category, expenditure on the electricity used for all possible tasks in the household was taken into account. The expenditure on energy carriers in the analyzed period is presented in Table 3.

Table 1. Households in the surveyed countries.

\begin{tabular}{cccc}
\hline \multirow{2}{*}{ Country } & Population & Number of Households & \multirow{2}{*}{ Average People in a Household } \\
\cline { 2 - 3 } & \multicolumn{3}{c}{ In Thousand } \\
\hline Poland & 37,977 & 14,440 & 2.6 \\
Portugal & 10,291 & 4145 & 2.5 \\
Italy & 60,484 & 25,936 & 2.3 \\
\hline
\end{tabular}

Source: Own study based on Eurostat data from 2020. https://stat.gov.pl/download/gfx/portalinformacyjny/en/defaultaktualnosci/33 04/1/9/1/energy_2021.pdf (accessed on 3 June 2021).

Table 2. Energy consumption of household appliances (data from 2020).

\begin{tabular}{|c|c|c|c|}
\hline & Poland & Portugal & Italy \\
\hline Energy Consumption & & Average & \\
\hline Space heating & $59 \%$ & $45 \%$ & $55 \%$ \\
\hline Water heating & $10 \%$ & $10 \%$ & $9 \%$ \\
\hline Food cooking appliances & $11 \%$ & $5 \%$ & $3 \%$ \\
\hline Mechanical ventilation and air conditioning equipment & $4 \%$ & $25 \%$ & $21 \%$ \\
\hline Apartment lighting & $5 \%$ & $4 \%$ & $3 \%$ \\
\hline Household appliances and electronics & $3 \%$ & $1 \%$ & $1 \%$ \\
\hline Equipped with measuring and regulating devices & $4 \%$ & $3 \%$ & $3 \%$ \\
\hline Passenger cars in households & $7 \%$ & $7 \%$ & $8 \%$ \\
\hline
\end{tabular}

Source: Own study based on Eurostat data from 2020. https://stat.gov.pl/download/gfx/portalinformacyjny/en/defaultaktualnosci/33 04/1/9/1/energy_2021.pdf (accessed on 3 June 2021).

Table 3. Household expenditure on energy carriers in 2020.

\begin{tabular}{cccc}
\hline Itemized Expenditure & & Country & Portugal \\
\cline { 2 - 4 } & Poland & 443 & 489 \\
Household expenses & 356 & 49,57 & 51,61 \\
Total [EUR/person] & 46,28 & $8 \%$ & $9 \%$ \\
Expenditure on energy carriers [EUR/person] & $11 \%$ & & Italy \\
\hline
\end{tabular}

Source: Own study based on Eurostat data from 2020. https://stat.gov.pl/download/gfx/portalinformacyjny/en/defaultaktualnosci/33 04/1/9/1/energy_2021.pdf (accessed on 3 June 2021).

Expenditure on energy is of a similar value in the analyzed countries, clearly indicated by the percentage. An important aspect is also the indicated expenditure regarding equal social groups. The share of energy expenditure in the average monthly expenditure per capita in households by socio-economic groups is shown in Figure 1.

The analysis of data on expenditure on electricity in the studied countries allows for the conclusion that the selection of the sample and countries for the study was correct. To examine the social context and answer research questions after analyzing the literature and presented data, a research hypothesis was made:

Hypothesis 1 (H1). The knowledge possessed by citizens influences the ability to manage the energy resources consumed by the household. 


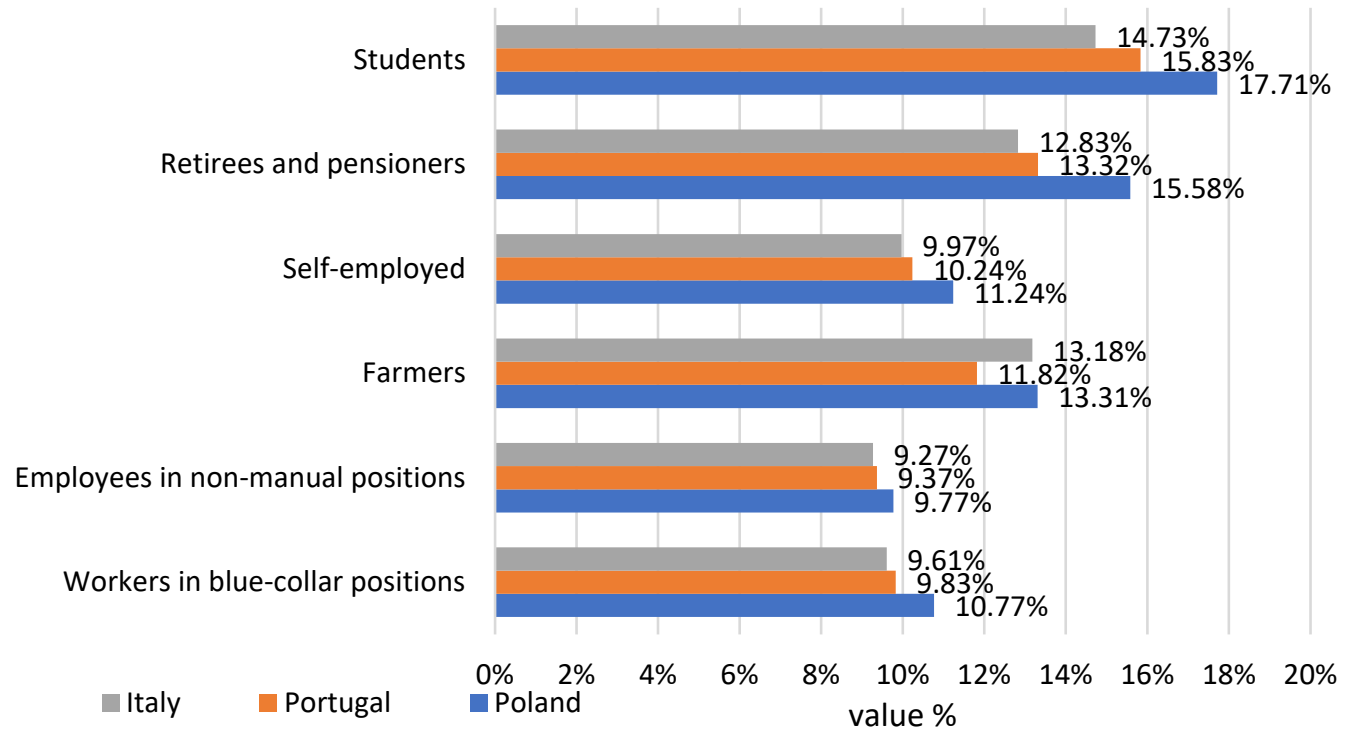

Figure 1. Energy expenditure in the household budget broken down by professional groups (per person).

\section{Results and Discussion}

In order to verify the presented research hypotheses, the previously described research was carried out. In terms of materials and methods, the empirical component, included the development and analysis of the quantitative and qualitative results, was carried out with the use of questionnaire.

The most popular way of saving energy in households in the first group of activities is by turning off lights in unused rooms (in $64 \%$ of households). A common activity limiting energy consumption in apartments is also turning on the thermostat at radiators during airing (32\%) and avoiding the "standby" mode in electronics / household appliances $(29 \%)$. The most common solution for reducing energy consumption, related to additional expenses, is the use of energy-saving light sources. Such activity was declared by $47 \%$ of the households surveyed. In order to protect an apartment against energy loss, 38\% of respondents seal windows, and $17 \%$ insulate roofs and walls. The respondents emphasized that over the last three years, they more often remember about the principles of energy saving, voluntarily participate in webinars and subscribe to social media groups where they can share their knowledge about energy saving. The respondents paid attention not only to the ways of saving (Figure 2) but also to the reasons for saving (Figure 3). The analysis of these preliminary data allowed to define further research activities and facilitated the use of the SERVPERF method.

By analyzing data on the methods and reasons for saving, the figures were tested with $X^{2}$ at a significance level of $\alpha=0.01$. Then, the Pearson's correlation coefficient was calculated, which indicates the strength of the relationship between the factors (exemplary relationships are presented in the Table 4). Examination of these relationships allowed us to adopt the SERVPERF method as a research tool to illustrate the level of knowledge.

The statistical analysis illustrated on Table 4 shows strong relationships between the examined factors, which allowed for the quality assessment methods and the results application that can be obtained as a result of their application. The SERVPERF method was chosen to assess consumer satisfaction [52]. This method is characterized by taking into account only the subjective assessment of the consumer's perceptions, while expectations are excluded from the assessment [53,54]. The general formula of the method is very simple, which makes it easier to apply from a practical point of view. The quality of service (Q) is compared here to the customer's perception (P) [55-58]. This is the second part of the study in which the SERVPERF method was used (with using the seven-point Likert scale) in Table 5. 
installation of energy harvesting systems

use of economic energy tariffs

thermo-modernization

avoiding standby mode in electronics and household appliances

screwing radiators (e.g. during airing)

purchase of energy-saving household appliances

sealing windows

use of energy-saving light sources

switching off lights in unused rooms

I'm not saving energy

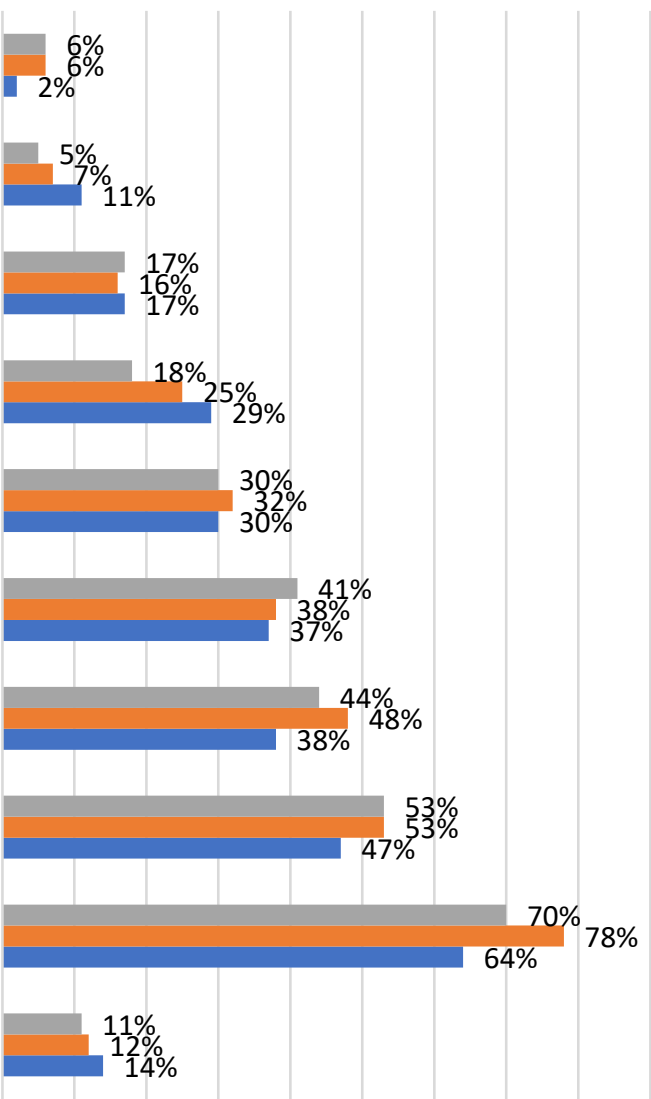

$\begin{array}{lllllllllll}0 & 0 & 10 \% & 20 \% & 30 \% & 40 \% & 50 \% & 60 \% & 70 \% & 80 \% & 90 \%\end{array}$ n Italy a Portugal a Poland

Figure 2. Energy saving methods.

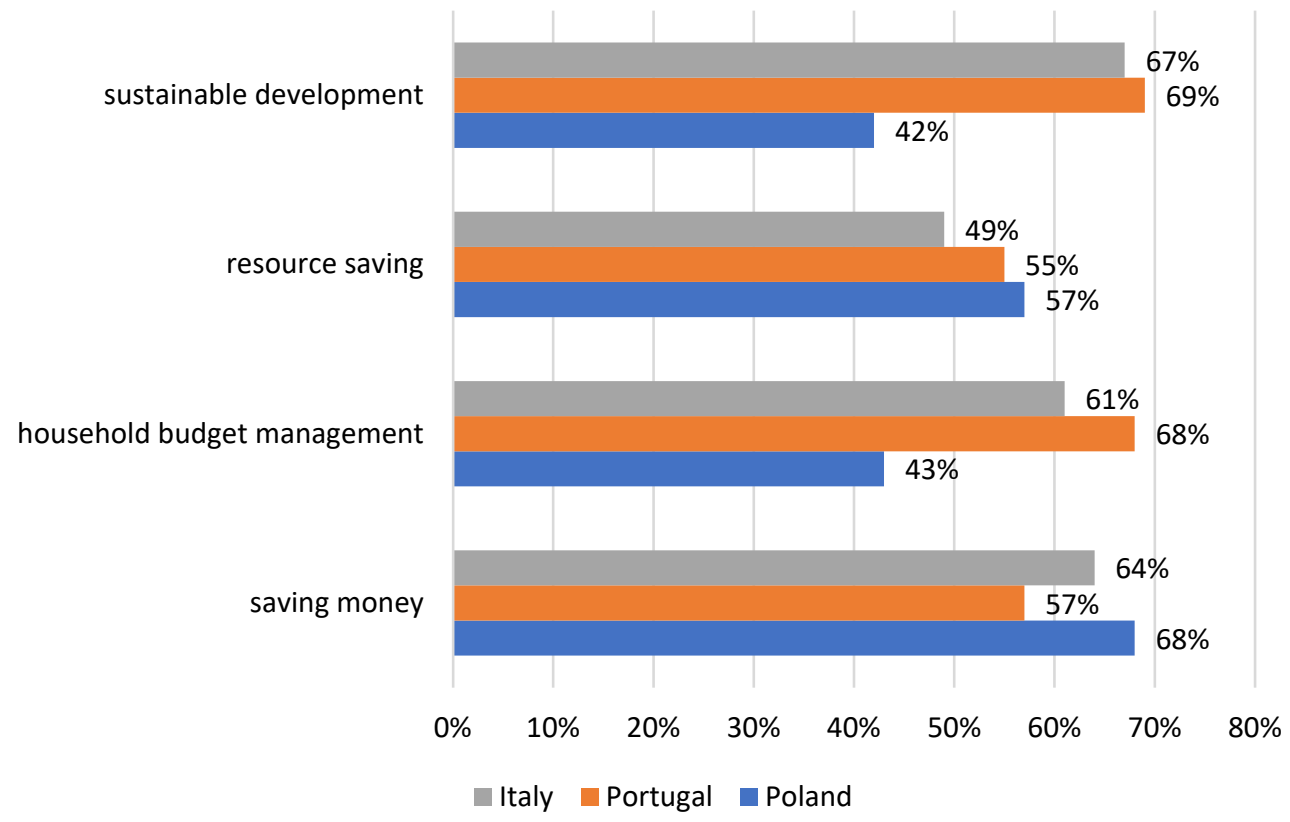

Figure 3. Reasons for saving energy. 
Table 4. Relationship analysis-Pearson's C index.

\begin{tabular}{ccc}
\hline Value & Strength Value & Dependence \\
0,81 & Very strong & being eco-friendly/being concerned with household costs \\
0,63 & Strong & being ecological/being interested in technological novelties \\
0,59 & Strong & application of energy saving methods/household management \\
0,78 & Very strong & pro-social behavior/being ecological \\
0,75 & Very strong & access to information on energy saving/ecological behavior \\
\hline
\end{tabular}

Table 5. SERVPERF analysis for energy saving behavior.

\begin{tabular}{|c|c|c|}
\hline Quality Dimensions & nr & Quality Criteria \\
\hline \multirow{3}{*}{ Perception of key features } & 1 & the quality of the information provided \\
\hline & 2 & quality of offered solutions and applications \\
\hline & 3 & quality of savings calculation methods \\
\hline \multirow{4}{*}{ Reliability } & 4 & knowledge acquisition speed \\
\hline & 5 & willingness to learn saving methods \\
\hline & 6 & security of applied solutions \\
\hline & 7 & trust in new methods and applications \\
\hline \multirow[b]{2}{*}{ Reaction to the consumer's needs } & 8 & the range of savings opportunities offered \\
\hline & 0 & speed of reacting to changes \\
\hline \multirow{3}{*}{ Confidence of implementation } & & \\
\hline & 10 & credibility of the knowledge obtained \\
\hline & 11 & the ability to use knowledge to save \\
\hline
\end{tabular}

In Figure 4 the average values of evaluations given by respondents to individual determinants were presented, while in Figure 5 these values were compared to the ideal evaluation (evaluation in Liker's scale).

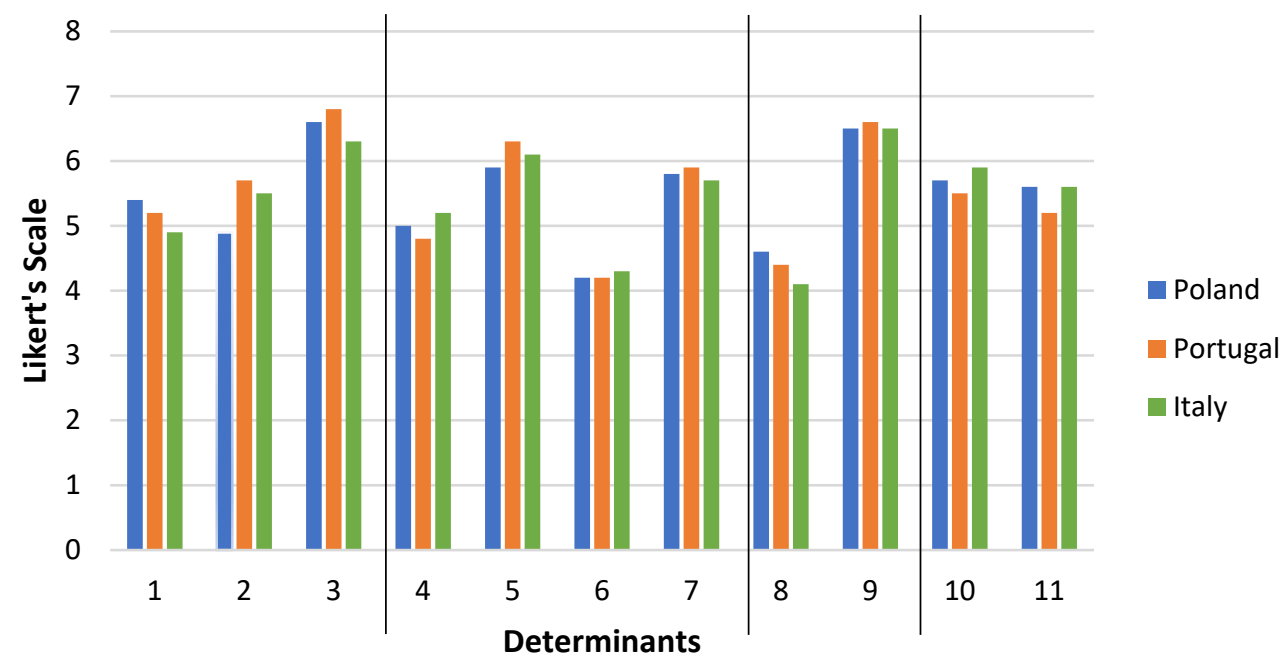

Figure 4. Aggregated results for the SERVPERF method.

Figures 4 and 5 present the Likert scale of the respondents in each country and the assigned percentages. It is clearly visible that determinants 3, 5 and 9 were rated as the highest. While the quality of the calculation methods allows the person who plans the expenses to estimate the size of the bill, there is also certainly a noticeable desire to learn about saving methods, which causes a snowball effect, resulting in the head of the family motivating all household members to save energy. One person with an ecological attitude is enough, who cares for the functioning of the planet or simple economic savings, and the rest join it in most cases. Moreover, the speed and the ability to react to changes are equally important. The changes may include new tariffs for servicing new farms on the market, or 
new technological solutions allowing for energy saving. The average values of each group were shown in Figure 6.

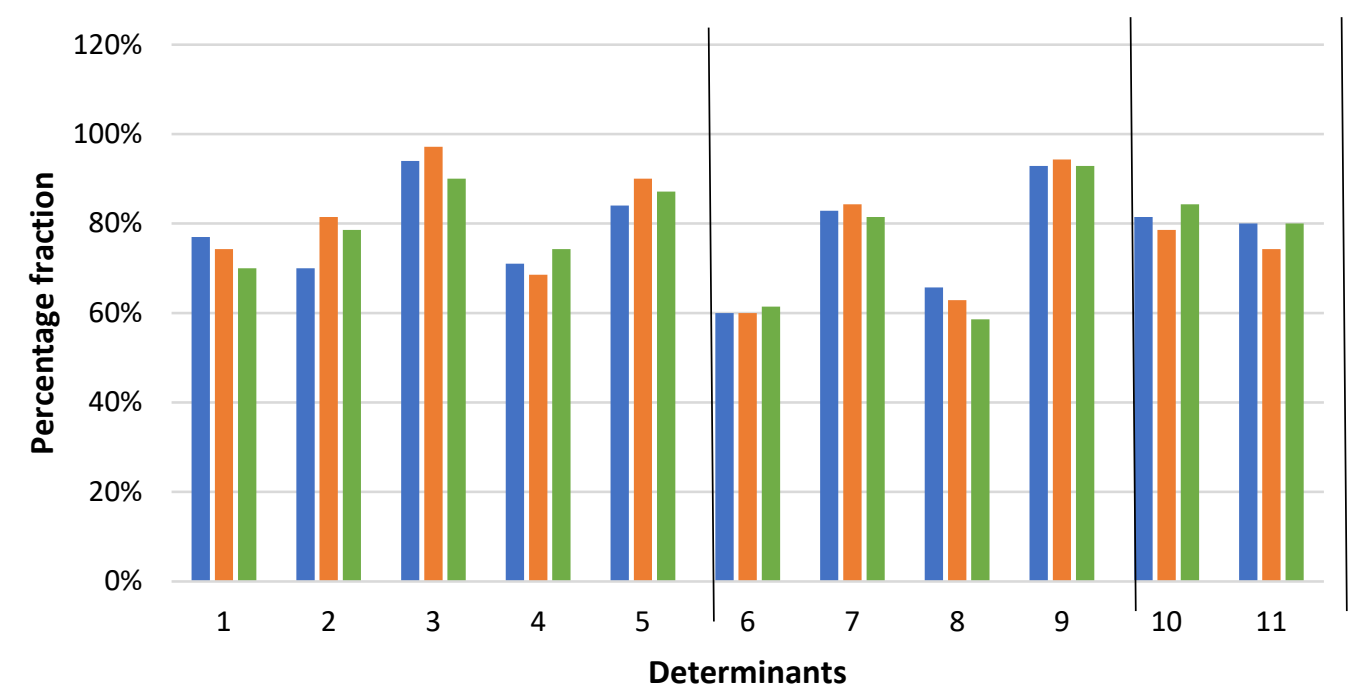

Figure 5. Percentage in relation to the Likert's scale for the SERVPERF method.

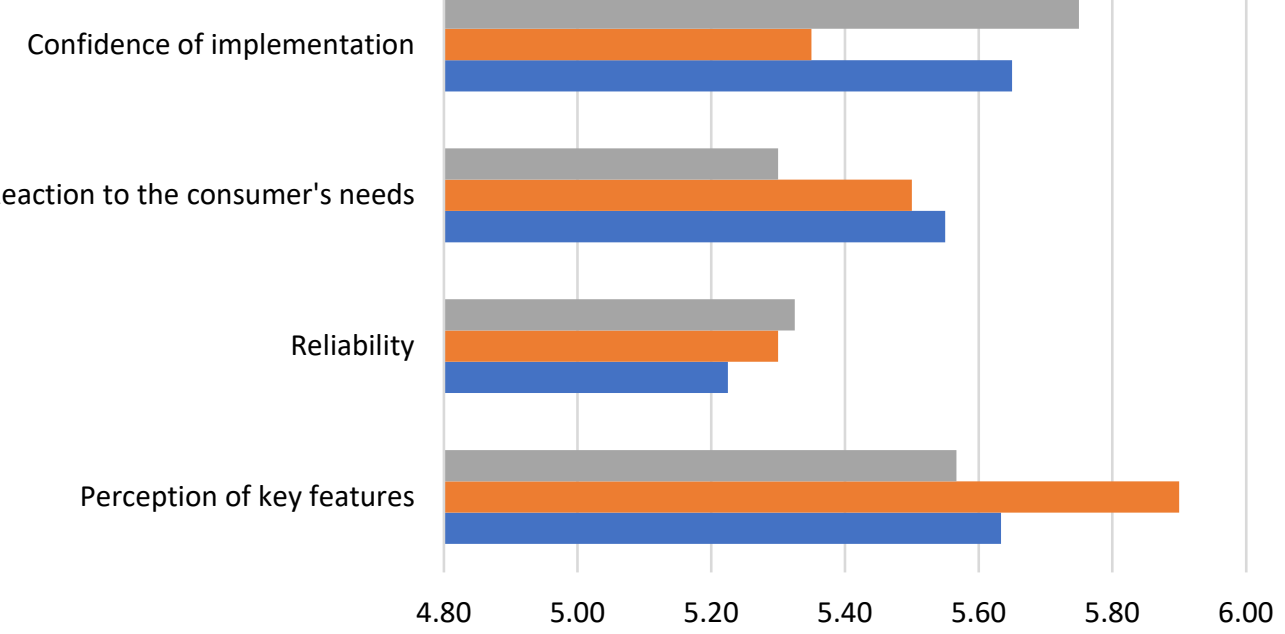

Average values of individual group of determinants

$$
\text { - Italy } \square \text { Portugal } \square \text { Poland }
$$

Figure 6. Average values of individual group of determinants.

The total average value for all determinants was also calculated. This calculation was made in two different ways: as an arithmetic average XA and as weighted average XW [59].

$\mathrm{XA}=5.28$

$\mathrm{XW}=5.26$

On average, determinants were evaluated at 5.28, and after taking into account weights, the average was 5.26 (not much lower than the arithmetic average), meaning that the determinants were evaluated at a level above the average. Referring both averages to ideal evaluation, it was $83.95 \%$ and $83.73 \%$, meaning that, on average, $84 \%$ meet the expectations of households.

The conducted research makes it possible to unequivocally determine that the respondents in all surveyed countries use similar methods of saving energy. The behaviors that they offer are shown in Figure 2. The second research question concerns the level of cycling 
knowledge with behaviors aimed at saving energy, and the SERVPERF analysis allowed to identify the factors that determine the level of knowledge and commitment. The quality of the methods for calculating savings indicated that the respondents showed a desire for methods and the ability of household managers to use them. The willingness to learn about saving methods illustrates the need to broaden the knowledge. On the other hand, the speed of responding to changes verifies that the state of knowledge allows consumers to react to the ongoing technological, economic and IT changes and to adjust them for energy-saving behavior.

The conducted research illustrates the current state of knowledge in individual countries and the ability to use it, but the result is not satisfactory [29,64]. A significant proportion of the respondents do not save energy for various reasons. They do not analyze their behavior, so it is difficult to talk about pro-social or pro-ecological behavior. Authors are also critical of the ratings given by the respondents for the SERVPERF method. Only three ratings are relatively high, which means that knowledge is at an average level and still requires a lot of consumer involvement in training in this area.

\section{Conclusions}

The deepening ecological and social problems imply the shaping of sustainable consumer attitudes and behaviors in households. The expression of adopting the principles of new methods of consumption is the search for the possibility of saving energy for households and the conscious limitation of this good consumption that is obtained from non-renewable resources, for the so-called "clean" energy.

Research conducted in the field of the level of energy expenditure, energy consumption and pro-environmental activities show that the adaptation of sustainable consumption postulates takes place faster in the declarative sphere than in the real sphere. Although the vast majority ( $86 \%$ in 2019 and $94 \%$ in 2020) of the surveyed households believe that they save energy, the percentage share of their energy expenditure in total expenditure is constantly growing. The determinants of the observed dissonance of declarations and behaviors should be sought beyond the level of ecological awareness, for example in the subjective assessment of the financial situation of the household or the country economic condition. It seems necessary to direct transformational activities towards increasing the share of so-called "clean" energy consumption, which will allow, in the long term, to reduce expenditure on energy carriers and slow down the degradation of the natural environment, contributing to the improvement of people's quality of life.

The problem presented in the introduction, and described by the hypothesis and research problems, was supported by the related research described in the literature. The conducted research allowed for the energy saving identification methods, and the use of the SERVPERF method allowed us to determine the level of knowledge. Thanks to the services evaluation offered, the possibility of using these solutions was described in the method.

The conducted study fills the research gap, while previous studies have indicated behaviors and defined their behavior trends. However, there is a lack of studies that compare the state of knowledge with behavior. The selection of the research method and the use of SERVPERF allowed us to determine how consumers gain the knowledge, what trends they follow to be pro-active, what is important to them during energy saving and what motivates them. The authors decided that the next stage of the research would be to divide the respondents by age (generation) and place of residence, and to indicate the relationship in their behavior.

Author Contributions: Conceptualization, J.Ż. and M.M.; methodology, J.Ż.; software, J.R.-S.; validation, J.R.-S.; formal analysis, M.M.; investigation, J.Ż.; resources, J.Ż.; data curation, M.M.; writingoriginal draft preparation, J.Ż., J.R.-S.; writing-review and editing, J.Ż.; visualization, M.M. All authors have read and agreed to the published version of the manuscript.

Funding: This research received no external funding.

Institutional Review Board Statement: Not applicable. 
Informed Consent Statement: Not applicable.

Data Availability Statement: Not applicable.

Conflicts of Interest: The authors declare no conflict of interest.

\section{References}

1. Mukherjee, A. (Ed.) Sustainable Households. In Penury into Plenty; Routledge: London, UK, 2014; pp. 161-210. ISBN 9781315739182.

2. Appel-Meulenbroek, R.; Weggeman, M.; Torkkeli, M. Knowledge sharing behaviour within organisations; a diary-based study of unplanned meetings between researchers. Knowl. Manag. Res. Pract. 2018, 16, 267-279. [CrossRef]

3. Connolly, D.; Lund, H.; Mathiesen, B.V.; Leahy, M. Modelling the existing Irish energy-system to identify future energy costs and the maximum wind penetration feasible. Energy 2010, 35, 2164-2173. [CrossRef]

4. Edmondson, A.C. The Fearless Organization: Creating Psychological Safety in the Workplace for Learning, Innovation, and Growth; John Wiley \& Sons: Hoboken, NJ, USA, 2018.

5. Eid, M.; Nuhu, N.A. Impact of learning culture and information technology use on knowledge sharing of Saudi students. Knowl. Manag. Res. Pract. 2011, 9, 48-57. [CrossRef]

6. Bernard, J.; Delprat, S.; Guerra, T.M.; Büchi, F.N. Fuel efficient power management strategy for fuel cell hybrid powertrains. Control Eng. Pract. 2010, 18, 408-417. [CrossRef]

7. Haeussler, C.; Jiang, L.; Thursby, J.; Thursby, M. Specific and general information sharing among competing academic researchers. Res. Policy 2014, 43, 465-475. [CrossRef]

8. Göksel, A.; Aydıntan, B. How can tacit knowledge be shared more in organizations? A multidimensional approach to the role of social capital and locus of control. Knowl. Manag. Res. Pract. 2017, 15, 34-44. [CrossRef]

9. Lauritzen, G.D.; Karafyllia, M. Perspective: Leveraging Open Innovation through Paradox. J. Prod. Innov. Manag. 2019, 36, 107-121. [CrossRef]

10. Żywiołek, J. Determinants of the safety of railway passengers using the internet in Poland. Multidiscip. Asp. Prod. Eng. 2019, 2, 508-514. [CrossRef]

11. Sáfián, F. Modelling the Hungarian energy system-The first step towards sustainable energy planning. Energy 2014, 69, 58-66. [CrossRef]

12. Rice, R.E.; Heinz, M.; van Zoonen, W. A public goods model of outcomes from online knowledge sharing mediated by mental model processing. J. Knowl. Manag. 2019, 23, 1-22. [CrossRef]

13. Zheng, C.H.; Kim, N.W.; Cha, S.W. Optimal control in the power management of fuel cell hybrid vehicles. Int. J. Hydrogen Energy 2012, 37, 655-663. [CrossRef]

14. Zheng, C.H.; Oh, C.E.; Park, Y.I.; Cha, S.W. Fuel economy evaluation of fuel cell hybrid vehicles based on equivalent fuel consumption. Int. J. Hydrogen Energy 2012, 37, 1790-1796. [CrossRef]

15. Zheng, C.; Cha, S.W.; Park, Y.; Lim, W.S.; Xu, G. PMP-based power management strategy of fuel cell hybrid vehicles considering multi-objective optimization. Int. J. Precis. Eng. Manuf. 2013, 14, 845-853. [CrossRef]

16. Stadler, R. Cultural Elements of Knowledge Management. In Knowledge Management in Event Organisations; Stadler, R., Ed.; Goodfellow Publishers: Oxford, UK, 2021; ISBN 9781911635444.

17. Verma, S. Personal Knowledge Management: A Tool to Expand Knowledge about Human Cognitive Capabilities. IJET 2009, 1, 435-438. [CrossRef]

18. Young, D. When do energy-efficient appliances generate energy savings? Some evidence from Canada. Energy Policy 2008, 36, 34-46. [CrossRef]

19. Zheng, C.; Xu, G.; Xu, K.; Pan, Z.; Liang, Q. An energy management approach of hybrid vehicles using traffic preview information for energy saving. Energy Convers. Manag. 2015, 105, 462-470. [CrossRef]

20. Fredrickson, B.L.; Joiner, T. Reflections on Positive Emotions and Upward Spirals. Perspect. Psychol. Sci. 2018, 13, 194-199. [CrossRef]

21. Hernaus, T.; Cerne, M.; Connelly, C.; Poloski Vokic, N.; Škerlavaj, M. Evasive knowledge hiding in academia: When competitive individuals are asked to collaborate. J. Knowl. Manag. 2019, 23, 597-618. [CrossRef]

22. Foege, J.N.; Lauritzen, G.D.; Tietze, F.; Salge, T.O. Reconceptualizing the paradox of openness: How solvers navigate sharingprotecting tensions in crowdsourcing. Res. Policy 2019, 48, 1323-1339. [CrossRef]

23. Fawkes, S. (Ed.) Outsourcing Energy Management; Routledge: London, UK, 2017; ISBN 9781315599267.

24. Lund, H.; Andersen, A.N.; Østergaard, P.A.; Mathiesen, B.V.; Connolly, D. From electricity smart grids to smart energy systems-A market operation based approach and understanding. Energy 2012, 42, 96-102. [CrossRef]

25. Nelson, A.J. How to Share "A Really Good Secret": Managing Sharing/Secrecy Tensions Around Scientific Knowledge Disclosure. Organ. Sci. 2016, 27, 265-285. [CrossRef]

26. Radder, H. Which Scientific Knowledge is a Common Good? Soc. Epistemol. 2017, 31, 431-450. [CrossRef]

27. Shibayama, S. Academic commercialization and changing nature of academic cooperation. J. Evol. Econ. 2015, $25,513-532$. [CrossRef] 
28. Perumal, S.; Sreekumaran Nair, S. Impact of views about knowledge and workplace relationships on tacit knowledge sharing. Knowl. Manag. Res. Pract. 2021, 1-12. [CrossRef]

29. Vicente-Saez, R.; Martinez-Fuentes, C. Open Science now: A systematic literature review for an integrated definition. J. Bus. Res. 2018, 88, 428-436. [CrossRef]

30. Żywiołek, J. Social Media about the Company's Image as an Element of Specific Development. Preprints 2021, 2021060685. [CrossRef]

31. Wipawayangkool, K.; Teng, J.T.C. Paths to tacit knowledge sharing: Knowledge internalization and individual-task-technology fit. Knowl. Manag. Res. Pract. 2016, 14, 309-318. [CrossRef]

32. Valerio-Ureña, G.; Rogers, R. Characteristics of the Digital Content about Energy-Saving in Different Countries around the World. Sustainability 2019, 11, 4704. [CrossRef]

33. Żywiołek, J.; Rosak-Szyrocka, J.; Jereb, B. Barriers to Knowledge Sharing in the Field of Information Security. Manag. Syst. Prod. Eng. 2021, 29, 114-119. [CrossRef]

34. Żywiołek, J.; Schiavone, F. Perception of the Quality of Smart City Solutions as a Sense of Residents' Safety. Energies 2021, $14,5511$. [CrossRef]

35. Yeo, R.K.; Marquardt, M.J. To share or not to share? Self-perception and knowledge-sharing intent. Knowl. Manag. Res. Pract. 2015, 13, 311-328. [CrossRef]

36. Ziemba, E. Factors Affecting the Adoption and Usage of ICTs within Polish Households. J. Inf. Knowl. Manag. 2016, 11, 89-113. [CrossRef]

37. Zhu, Y.-Q.; Chiu, H.; Infante Holguin-Veras, E.J. It is more blessed to give than to receive: Examining the impact of knowledge sharing on sharers and recipients. J. Knowl. Manag. 2018, 22, 76-91. [CrossRef]

38. Yue, T. Research on Influencing Factors and Guiding Policy of Energy-conservation Behavior of Urban Residents. Ph.D. Thesis, China University of Mining and Technology, Xuzhou, China, 2014.

39. Yi, J. A measure of knowledge sharing behavior: Scale development and validation. Knowl. Manag. Res. Pract. 2009, 7, 65-81. [CrossRef]

40. Zografakis, N.; Karyotakis, K.; Tsagarakis, K.P. Implementation conditions for energy saving technologies and practices in office buildings: Part 1. Lighting. Renew. Sustain. Energy Rev. 2012, 16, 4165-4174. [CrossRef]

41. Zheng, C.; Xu, G.; Jeong, J.; Cha, S.W.; Park, Y.; Lim, W. Power source sizing of fuel cell hybrid vehicles considering vehicle performance and cost. Int. J. Precis. Eng. Manuf. 2014, 15, 527-533. [CrossRef]

42. Whitfield, M.B. Strategies: Energy IT and Business Process Outsourcing-Key Concepts and Trends. Nat. Gas Elec. 2014, 31, 24-27. [CrossRef]

43. Saving Money by Saving Energy (Fact Sheet); National Renewable Energy Laboratory (U.S.): Golden, CO, USA, 2011.

44. Al Mamun, M.; Hoque, M.A.; Hossain, M.T.; Yasmeen, F. Managing the future megacity: An appraisal of knowledge about energy challenges and energy-saving attitudes among households in Dhaka. Int. J. Sustain. Energy 2016, 35, 701-721. [CrossRef]

45. Borges, R.; Bernardi, M.; Petrin, R. Cross-country findings on tacit knowledge sharing: Evidence from the Brazilian and Indonesian IT workers. JKM 2019, 23, 742-762. [CrossRef]

46. Alberg Østergaard, P.; Mathiesen, B.V.; Möller, B.; Lund, H. A renewable energy scenario for Aalborg Municipality based on low-temperature geothermal heat, wind power and biomass. Energy 2010, 35, 4892-4901. [CrossRef]

47. Zaikin, A. Development of ideas about the information society (historical and legal analysis). Knowl. Educ. Law Manag. 2020, 3, 54-58. [CrossRef]

48. Dahlander, L.; Gann, D.M. How open is innovation? Res. Policy 2010, 39, 699-709. [CrossRef]

49. Connolly, D.; Lund, H.; Mathiesen, B.V.; Werner, S.; Möller, B.; Persson, U.; Boermans, T.; Trier, D.; Østergaard, P.A.; Nielsen, S. Heat Roadmap Europe: Combining district heating with heat savings to decarbonise the EU energy system. Energy Policy 2014, 65, 475-489. [CrossRef]

50. Brandoni, C.; Arteconi, A.; Ciriachi, G.; Polonara, F. Assessing the impact of micro-generation technologies on local sustainability. Energy Convers. Manag. 2014, 87, 1281-1290. [CrossRef]

51. Ingaldi, M.; Dziuba, S.T. charakterystyka gospodarstw domowych z ekologicznego punktu widzenia. QPI 2018, 8, 52-65. [CrossRef]

52. Jonek-Kowalska, I.; Wolniak, R. Economic opportunities for creating smart cities in Poland. Does wealth matter? Cities 2021, 114, 103222. [CrossRef]

53. Amine Chatti, M. Knowledge management: A personal knowledge network perspective. J. Knowl. Manag. 2012, 16, 829-844. [CrossRef]

54. The E-Dimension of Knowledge Management. In Knowledge Management; Frappaolo, C. (Ed.) John Wiley \& Sons, Inc: Hoboken, NJ, USA, 2012; pp. 31-42. ISBN 9781907312175.

55. Wolniak, R.; Saniuk, S.; Grabowska, S.; Gajdzik, B. Identification of Energy Efficiency Trends in the Context of the Development of Industry 4.0 Using the Polish Steel Sector as an Example. Energies 2020, 13, 2867. [CrossRef]

56. Becerra-Fernandez, I.; Gonzalez, A.; Sabherwal, R. Knowledge Management: Challenges, Solutions, and Technologies; Pearson/Prentice Hall: Hoboken, NJ, USA, 2004.

57. Martín-de-Castro, G.; López-Sáez, P.; Navas-López, J.E. Processes of knowledge creation in knowledge-intensive firms: Empirical evidence from Boston's Route 128 and Spain. Technovation 2008, 28, 222-230. [CrossRef] 
58. Wang, S.; Noe, R.A. Knowledge sharing: A review and directions for future research. Hum. Resour. Manag. Rev. 2010, 20, 115-131. [CrossRef]

59. Wu, W.-L. To Share Knowledge or Not: Dependence on Knowledge-Sharing Satisfaction. Soc. Behav. Personal. Int. J. 2013, 41, 47-58. [CrossRef]

60. Sheng, P.; Dong, Y.; Vochozka, M. Analysis of Cost-Effective Methods to Reduce Industrial Wastewater Emissions in China. Water 2020, 12, 1600. [CrossRef]

61. Alsalemi, A.; Sardianos, C.; Bensaali, F.; Varlamis, I.; Amira, A.; Dimitrakopoulos, G. The Role of Micro-Moments: A Survey of Habitual Behavior Change and Recommender Systems for Energy Saving. IEEE Syst. J. 2019, 13, 3376-3387. [CrossRef]

62. Alizadeh, R.; Lund, P.D.; Soltanisehat, L. Outlook on biofuels in future studies: A systematic literature review. Renew. Sustain. Energy Rev. 2020, 134, 110326. [CrossRef]

63. Shao, Y.; Li, P. The Analysis of Design Methods about High-Rise Public Building Energy Saving. AMR 2012, 575, 84-89. [CrossRef]

64. Ghodsvali, M.; Krishnamurthy, S.; de Vries, B. Review of transdisciplinary approaches to food-water-energy nexus: A guide towards sustainable development. Environ. Sci. Policy 2019, 101, 266-278. [CrossRef] 